\title{
INTEGRASI ILMU PENGETAHUAN (SAINS) DAN AGAMA ISLAM
}

\author{
Feiza Rahma Putri \\ rfeiza19@gmail.com \\ Institut Agama Islam Negeri Purwokerto
}

DOI: $10.21580 /$ wa.v6i1.4848

\begin{abstract}
The integration of science (science) and Islamic religion does have a different point of view. But in this case, the harmony between the two must be improved. Because both have important roles in human life and the progress of a nation. Religion is a guideline or procedure or direction through the rules in the holy book which in science (science) is oriented towards communication interactions that exist in society. Both of them certainly have a relationship which integrates behavior, morals, ethics and society.
\end{abstract}

Keywords: Relation, Science, Islamic Religion

\begin{abstract}
Abstrak
Integrasi ilmu pengetahuan (sains) dan agama islam memanglah memiliki sudut pandang yang berbeda. Namun dalam hal ini, keselarasan antara keduanya haruslah ditingkatkan. Karena keduanya memiliki peran penting dalam kehidupan manusia dan kemajuan sebuah bangsa. Agama merupakan pedoman atau tata cara atau petunjuk melalui aturan di dalam kitab suci dimana dalam ilmu pengetahuan (sains) yang berorientasi pada interaksi komunikasi yang ada di dalam masyarakat. Keduanya tentu memiliki hubungan dimana berintegrasi pada perilaku, moral, etika dan kemasyarakatan.
\end{abstract}

Keywords: Hubungan, Ilmu Pengetahuan, Agama Islam

\section{A. Pendahuluan}

Banyak yang beraanggapan bahwa sains dan agama itu memiliki posisi masingmasing yang mana ilmu dalam memperoleh suatu kebenaran itu didasarkan pada perolehan data secara epistimologis melalui beberapa penelitian. Sedangkan agama dalam memperoleh 
kebenaran itu dengan menerima yang ghaib yang mana hal tersebut berlandaskan pada "iman" dan kepercayaan. Hal tersebut menjadikan bahwa integrasi agama dan sains itu tidak tepat untuk dijadikan kriteria ilmiah untuk mengidentifikasi sebuah kebenaran.

Persoalan apa yang menjadikan perdebatan antara kaum idealis dan kaum empiris? Mengapa dunia islam mengalami kemunduran? menurut pandangan ibnu khaldun dikarenakan hancur dan rusaknya sumber daya manusia, baik secara intelektual maupun moral. Tapi apakah ada alasan lain dibalik kemunduran tersebut? Untuk mengatasi hal tersebut, adakah metodologis yang tepat? Sehingga terjadinya keselarasan di dalam hubungan ilmu pengetahuan dan agama islam.

\section{B. Metode Penelitian}

Dalam penelitian ini digunakan sebuah metode yaitu literatur. Dimana didalamnya penulis mengumpulkan informasi dari beberapa sumber yang bersifat literatur yaitu buku, jurnal, dan yang lainnya. Penulisan tersebut, berawal dari sang penulis membaca buku, jurnal, ataupun yang lainnya kemudian mengambil beberapa pokok yang penting kemudian dijabarkan melalui pemahamannya. Setelah dibaca, kemudian dipahami, lalu dianalisis maka penulis mendapatkan suatu kesimpulan yang dapat ditarik.

\section{Pembahasan}

\section{Sejarah dan penerapan teori ilmu pengetahuan (sains) dan agama islam}

Menurut Quraish Shihab, kata ilmu dalam berbagai bentuk terdapat 854 kali dalam al-qur'an. Menurut islam, ilmu terbagi menjadi dua yaitu: ilmu yang bersifat materi ( dapat didengar, dilihat dan dirasakan). Kemudian ilmu yang bersifat non materi (spiritual, keyakinan dan motivasi ketenangan jiwa). ${ }^{1}$

Seorang ilmuwan Al-Kindi yang berasal dari Persia, Al-Farobi dan Ibnu Sina adalah seorang filsuf yang berfikir mendalam secara radikal yang menghasilkan ilmu pengetahuan. Banyak sekali para ilmuwan yang bekerja di istana-istana besar seperti Al-Kindi bekerja di istana khalifah ma'mun, Ar-Razi di istana Sultan Muhammad, Ibn Al-Haitham konsultan hakim, Ibn Sina sebagai dokter pribadi untuk para pangeran di beberapa kerajaan besar. Para penguasa tersebut tidak hanya memberikan gaji terhadap para ilmuwan tersebut. Namun juga memberikan kehormatan, perlindungan fisik, dimana hal tersebut banyak sekali serangan dari orang-orang fanatik yang beranggapan bahwa para ilmuwan tersebut menyeleweng dari ajaran agama dan harus dihilangkan dari pengaruh dalam masyarakat.

Banyak sekali para ilmuwan yang dalam pengembangan ilmu pengetahuan ini mendapatkan cobaan berupa fisik maupun tidak adanya dukungan dari para penguasa tertentu kemudian dikejar-kejar. Hal tersebut juga dialami oleh Galileo Galilei yang 3 tahun di dalam penjara dan mendapatkan siksaan karena para penguasa di gereja tidak mempercayai teori dari Galileo yang mana ia berpendapat bahwa bumi berputar mengelilingi matahari dan

${ }^{1}$ Zainal Arifin, "Pendidikan Islam Dalam Perspektif Filsafat Ilmu”, Jurnal Pendidikan Islam Vol XIX, Nomor 1, Juni 2014, hal. 131 
bukan matahari yang mengelilingi bumi. Walaupun teori itu benar dan pihak gerejalah yang salah menilai karya ilmuwan besar tersebut dan terlanjur menjatuhkan hukuman terhadapnya. Hal tersebut dapat dilihat, bahwa para ilmuwan tersebut kurang dukungan dari penguasa-penguasa untuk mengembangkan pemikirannya tentang ilmu pengetahuan. ${ }^{2}$

Setiap periode pertumbuhan dan perkembangan ilmu pengetahuan (sains) memiliki ciri khas yang berbeda-beda. Pada zaman yunani kuno abad (7-2 SM) merupakan zaman dimana disebut dengan zaman keemasan yang menjadi titik tumbuh ilmu pengetahuan modern. Pada zaman ini merupakan zaman dimana gudangnya ilmu pengetahuan dan filsafat. Pada zaman ini, bangsa yunani memiliki sikap yang kritis terhadap suatu fenomena yang ada. sikap kritis ini tentunya melahirkan banyak sekali tokoh. Salah satunya adalah Thales (624-548) yang mencoba menanyakan asal muasal alam semesta. kemudian ada Pythagoras (580-500SM) yang mempunyai keahlian di bidang ilmu ukur dan yang berpendapat bahwa bumi itu bundar tidak datar. Lalu ada Socrates (470-399 SM) seorang tokoh dialektika yang selalu mengutamakan proses dan mengajarkan kepada orang-orang untuk selalu berproses dan tidak mengharapkan hasil yang instan. Kemudian ada Democritos (460-370 SM) yang menemukan atom dan berpendapat bahwa alam semesta terbentuk dari susunan atom-atom. ${ }^{3}$ Selanjutnya ada Plato (427-374 SM) yang dikenal dengan seorang yang idealis dan rasionalis. Lalu ada murid dari Plato yaitu Aristotheles yang memiliki pandangan metafisika yang berbeda dengan Plato, namun ia juga ahli dalam bidang logika (sylogisme) dan biologi.

Zaman pertengahan (abad 2-14 M) yang mana zaman ini bekerja dan beroperasi untuk kepentingan agama. Namun dalam hal ini juga banyak temuan bidang ilmu, terutama zaman Bani Umayyah yang telah melakukan pengamatan tentang terjadinya alam semesta sebelum Galileo Galilei dan Copernicus. Pada abad ini, banyak sekali muncul sarjana-sarjana islam dalam bidang sains dan kebudayaan. Kemudian ada zaman renaissance (14-17 M) dimana zaman ini ditandai dengan kebangkitan sains. ${ }^{4}$

Agama itu untuk mencari ridho tuhan. Dimana dzat yang paling tinggi adalah tuhan. ${ }^{5}$ Agama islam yang awalnya pandangan tentang tuhan menurut masyarakat pra islam tetap mempercayai allah swt tetapi mereka menjadikan berhala-berhala sebagai media atau perantara bukan sebagai tuhan. Di dalam berhala itu, mereka mengibaratkan orang-orang sholeh. Karena menurut mereka Allah itu terlalu agung untuk dibayangkan. Kontruksi dasar tentang agama yang dapat diartikan bahwa agama merupakan suatu unsur utama yang membangun ikatan antar manusia yang dalam skala makro disebut dengan peradaban. Agama menurut mereka adalah suatu sistem keyakinan yang mana adapula yang mengartikan konsep agama merupakan konsep hutang piutang antara manusia dengan allah swt yang mencakup semua aspek kehidupan (dunia dan akhirat). Dalam konsep hutang piutang ini

\footnotetext{
${ }^{2}$ Achmad Baiquni, Al-qur'an dan Ilmu Pengetahuan Kealaman, (Yogyakarta: Dana Bhakti Prima Yasa, 1997), hal. 119

${ }^{3}$ Moh Dahlan, "Relasi Sains Modern dan Sains Islam: Suatu Upaya Pencarian Paradigma Baru", Jurnal Ilmu Pengetahuan Sains Vol 12, Nomor 2, Juli-Desember 2009, hal. 67

${ }^{4}$ Ibid, hal.68

${ }^{5}$ Nuraini, "Mengintegrasikan Agama, Filsafat, dan Sains", Jurnal Pendidikan Islam, vol. 2, Nomor 1, Juli-Desember 2016, hal. 114
} 
memiliki 4 makna yaitu: 1) keberhutangan, 2) ketundukan, 3) kekuatan hukum, 4) kecenderungan alamah. Agama sendiri dapat melahirkan suatu kebudayaan. Yang mana kebudayaan tersebut akan dilakukan secara turun menurun dan terus menerus.

Penerapan teori dalam kasus ini, peulis mengambil salah satu contoh teori alam semesta yaitu teori Big Bang.

Bagan 1 : Perbedaan epistimologi keilmuan islam dan barat

Teori bigbang : Alam semesta ( langit, bumi, dan seluruh benda angkasa) berasal dari satu kesatuan bola panas yang meledak menjadi bagian-bagian yang ada saat ini.
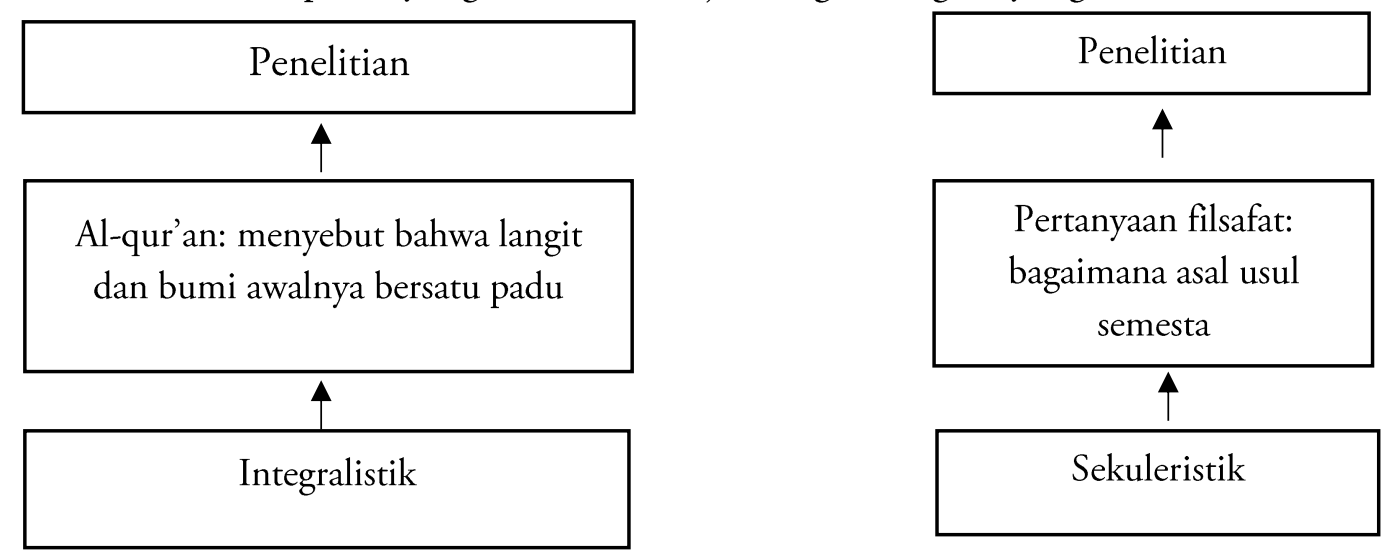

Dalam bagan tersebut, dijelaskan tentang teori bigbang menurut pandangan agama islam dan menurut barat. Di dalam al-qur'an disebutkan bahwa langit dan bumi awalnya itu memang satu. Penelitian yang dilakukan oleh ilmuwan muslim urutanya sama, yang menjadikan perbedaan adalah pada proses pencarian hasil dan hasil akhirnya. Contohnya dalam kasus teori bigbang tersebut. Dimana pada islam berawal dengan keimanan terhadap wahyu. Sedangkan sekuler berawal dari pertanyaan filsafat yang berorientasi kepada bidang keilmuan saja. Untuk ilmuwan islam sendiri yang bermula pada integralistik, teori big bang ini menjadi penguat landasan iman kepada tuhan. Sedangkan pada ilmuwan sekuler hanya berorientasi untuk bidang keilmuan saja. ${ }^{6}$

\section{Metodologis ilmu pengetahuan (sains) dan agama}

Al-ghazali membagi ilmu menjadi dua macam yaitu fardhu 'ain (ilmu agama) dan fardhu kifayah (ilmu non-agama). Yang mana fardhu 'ain adalah kewajiban setiap orang atau kewajiban pribadi, individual, ataupun personal masing-masing orang yang menjadikan prioritas dalam mempelajari ilmu. Sedangkan fardhu kifayah itu kewajiban setiap kelompok, dimana harus ada yang melaksanakannya, apabila tidak ada sama sekali maka satu kelompok tersebut salah atau berdosa. Dapat diartikan bahwa ilmu agama itu harus dikuasai setiap individu yang merupakan suatu kewajiban. Ketika ilmu agama sudah di pelajari, maka boleh selanjutnya mempelajari ilmu-ilmu lain. Pada pengertian tersebut, banyak orang yang salah mengartikan atau menafsirkan dari teori tersebut. Mereka lebih mementingkan ilmu agama,

${ }^{6}$ Fahri Hidayat, "Pengembangan Paradigma Integrasi Ilmu: Harmonisasi Islam dan Sains Dalam Pendidikan”, Jurnal Pendidikan Islam Vol IV, Nomor 2, Desember 2015, hal. 316 
dan menomorduakan ilmu non agama. Ketika teori itu disalah artikan maka perealisasian di dalam lembaga islam banyak sekali ilmu non agama yang tidak ada wadah untuk berkembang.

Cara untuk mendapatkan ilmu dinamakan epistimologis. Dari epistimologi menurut pandangan islam, ada 2 sudut pandang. Yaitu yang pertama, dengan usaha manusia itu sendiri, kemudian yang kedua adalah yang diberikan oleh Allah SWT. Pengetahuan yang diperoleh melalui usaha manusia itu ada 4: melalui indera, indera dan akal, akal, dan melalui qalb (hati). Sedangkan yang diberikan oleh Allah SWT adalah wahyu yang disampaikan kepda para rasul, ilham yang diterima oleh akal manusia, dan hidayah yang diterima oleh qalbu manusia.

Cara mendapatkan ilmu yang lain menurut tradisi barat terkenal 4 model atau cara yaitu: pertama logika formal, kedua penyelidikan empirik yang mana ini dilandasi dengan rasa inderawi dan pengalaman. Dimana seiring berjalannya waktu wujudnya akan selalu berubah. Ketiga pertimbangan normatif atau evaluatif. Keempat adalah synoptic atau menggunakan akal secara keseluruhan. ${ }^{7}$

Dalam tradisi keilmuan barat, science mempunyai beberapa ciri atau sifat yang menyebabkan ia disebut sebagai ilmu, yaitu: kegiatan, tata cara, dan pengetahuan. Pencirian ilmu sebagai kegiatan, tata cara, dan pengetahuan, tidak saling bertentangan, bahkan merupakan suatu kesatuan yang mesti ada secara runtut. Ilmu harus diusaahakan dengan kegiatan manusia, kegiatan harus dilaksanakan dengan tata cara tertentu, sehingga kegiatan yang menggunakan tata cara tertentu tersebut menjadi suatu pengetahuan. ${ }^{8}$ Ilmu secara nyata dan khas merupakan suatu rangkaian kegiatan yang dilakukan oleh para ilmuwan yang menggunakan pemikiran, menyangkut suatu pemahaman dan pengertian serta mempunyai tujuan-tujuan tertentu. Lebih tepatnya ilmu itu mengarah pada tujuan yang dijadikan keinginan oleh para ilmuwan.

Pada umumnya, ilmu itu dikembangkan oleh para ilmuwan untuk mencapai suatu kebenaran. Dari kebenaran tersebut menghasilkan banyak sekali tentang alam semesta, peristiwa yang ada didalam masyarakat, serta perilaku manusia. Menurut the liang gie, para ilmuwan untuk mencapai kebenaran, dalam melakukan kegiatannya menggunakan sistem yang alamiah. Pelaksanaan tata cara biasanya memeiliki pola-pola misalnya melakukan wawancara dana mengerjakan perhitungan. Ian G. Barbour dalam buku issus in science and religion bab kedelapan menulis tentang perbandingan metode agama dan sains yang berisi pembahasan mengenai: pertama kemiripan agama dan sains yang berisi tentang suatu pengalaman dan interpretasi, peran komunitas, dan analogi model. Kedua tentang peran aktif setiap orang terhadap konsentrasi puncak, teori biblikal dan teologi natural, interaksi iman (komitmen) dan akal (penemuan), komitmen dan pertanyaan reflektif. Selanjutnya tentang wahyu dan keunikan yang menyangkut ketergantungan agama terhadap peristiwa historis. Pada bagian pertama Barbour menyebutkan bahwa kesamaan metode antara sains dan agama

${ }^{7}$ Khudori Soleh, Epistimologi Ibn Rusyd: Upaya Mempertemukan Agama \& Filsafat, (Malang: UINMALIKI PRESS, 2012), hal.91-92

${ }^{8}$ Syarif Hidayatullah, “Agama dan Sains: Sebuah Kajian Tentang Relasi dan Metodologi”, Jurnal Filsafat Vol 29, Nomor 1, Februari 2019, hal.107 
paling tidak terdapat 3 hal $^{9}$ yaitu: dalam hubugan pengalaman dan interpretasi, peran komunitas agama dan paradigmanya, dan dalam penggunaan analogi dan model. Manusia memiliki kebutuhan yang terbagi menjadi dua macam yaitu: kebutuhan jasmani dan rohani. Dimana kebutuhan jasmani yang meliputi sains dan tekhnologi sedangkan kebutuhan rohani yang dipenuhi oleh moralitas dan agama.

Pandangan islam mengenai sains sangatlah terbuka. Dimana islam merupakan agama yang menganjurkan umatnya untuk memberikan segala kemampuan untuk menggunakan akalnya untuk memikirkan apa yang ada di alam semesta ini. Sebagaimana dalam surat arrahman ayat 33 yang artinya: hai jamaah, jin dan manusia, jika kamu sanggup menembus (melintasi) penjuru langit dan bumi, maka lintasilah, kamutidak dapat menembusnya kecuali dengan kekuatan”. Dalam ayat tersebut Allah SWT memberikan kesempatan terhadap manusia untuk menggunakan akalnya dan menjelajahi terhadap alam semesta. Rasulullah SAW pernah mengatakan bahwa tidak ada agama (islam) tanpa adanya aktifitas akal. Dimana hal tersebut penyeimbangan antara akal dan iman untuk mencari suatu kebenaran atas setiap fenomena atau permasalahan yang ada. Agama memiliki sifat yang umum, tetap, dan mengatur untuk kehidupan, sehingga dalam perealisasiannya antara agama dan masyarakat jika tidak seimbang maka akan sulit dipahami.

Contohnya pada kajian ilmu Ibnu Sina yang terbuka terhadap kitab suci, yang mana ia berusaha untuk mendapatkan kebenaran dari semua sumber. Dimana Ibnu Sina berpendapat bahwa manusia dan semesta memiliki hubungan yang sangat cocok. Dalam ilmu geologi, meteorologi, astronomi dan fisika beliau melakukan eksperimen dan observasi menjadi satu. Ibnu Sina dalam mengembangkan gagasannya memiliki perbedaan dengan yang lain, dimana perbedaanya terletak pada kualitas yang menjadi pokok dan yang menjadi tambahan. Dimana hal tersebut akan diterapkan pada seluruh alam. Hal tersebut juga diterapkan oleh Galileo Galilei, yang kemudian terciptalah ilmu fisika yang melihat dari perspektif kuantitas. ${ }^{10}$

\section{Pandangan Antara Ilmu Pengetahuan (sains) dan Agama}

Agama ketika dilihat dari segi kajian sosial adalah suatu pengakuan setiap masingmasing individu ataupun kelompok terhadap unsur suprasional yang mempengaruhi pembentukan sistem dan kelembagaan di tengah-tengah masyarakat. Oleh sebab itu, agama harus dipandang pada segi universal yang posisinya juga sangat pentig dalam kehidupan bermasyarakat. Di dalam agama terdapat nilai dan norma yang mengikat suatu masyrakat. Dimana keterikatan tersebut berlaku secara terus menerus yang kemudian menjadi suatu budaya di dalam masyarakat. Aturan tersebut dianggap sakral yang menuntut adanya kesepahaman diantara kelompok tersebut. Agama memiliki peran yang sangat penting dimana hal tersebut memunculkan sebuah pro kontra didalamnya. Banyaknya persinggungan antara ilmu pengetahuan dan agama yang mengharuskannya untuk memunculkan paradigma yang dapat memersatukan kedua unsur tersebut.

${ }^{9}$ Ibid, hal. 117

${ }^{10}$ Seyyed Hossein Nasr, Tiga Mazhab Utama Filsafat Islam (Ibnu Sina, Suhrawardi, dan Ibnu 'Arabi), (Yogyakarta: IRCiSoD, 2014), hal.63-64 
Kemunculan perbedaan pandangan antara ilmu pengetahuan dan agama terjadi karena perbedaan orientasi struktur sosial yang ingin dicapai di dalam suatu masyarakat. Sebenarnya antara ilmu pengetahuan dan agama itu memiliki keselarasan atau kesaman dalam perspektif sosial yaitu untuk mencapai tujuan dari manusia. Yang mana tujuan tersebut untuk kepentingan manusia itu sendiri, baik secara akal ataupun emosional. Disini dibutuhkan hal yang dapat membuka pemikiran dan sudut pandang manusia dimana pemahaman mereka sebenarnya keliru. Antara ilmu pengetahuan dan agama merupakan satu kesatuan, dimana kedua unsur tersebut sangat pnting dalam kehidupan dan untuk kemajuan sebuah bangsa.

Ketika dalam pandangan manusia tidak bisa mengintegrasikan antara ilmu pengetahuan dan agama maka tidak akan bisa maju. Ketika hanya salah satu aspek yang maju, maka akan adanya ketidakseimbangan. Contoh ketika ilmu pengetahuan kita memang tinggi, namun nilai agama kita rendah atau bahkan tidak ada. maka kita dalam mengontrol ilmu pengetahuan kita tidak dapat mencapai suatu tujuan. Karena dalam penggunaannya ilmu pengetahuan tersebut tidak ada pengendali atau pembatasnya. Namun berbeda ketika ada agama didalam meraih suatu tujuan ilmu pengetahuan. Maka akan ada pengontrol untuk mencapainya. Begitu pula ketika kita hanya mengandalkan agama tanpa adanya ilmu pengetahuan. Maka kita tidak akan bisa membuktikan dengan karya-karya ilmiah. Dimana kebenaran itu harus dibuktikan serta menyertakan bukti-bukti baik secara visual ataupun yang lainnya. Disini terbukti bahwa antara ilmu pengetahuan dan agama harus diintegrasikan untuk mencapai suatu kebenaran yang baik dan tepat.

\section{Hubungan ilmu pengetahuan sains dan agama islam}

Al-qur'an memerintahkan agar manusia mencari, menemukan, dan mempelajari ilmu. Yang mana perintah al-qur'an tersebut dapat dilihat dari 2 sudut pandang. Yang pertama, al-qur'an memerintahkan agar manusia menggunakan akal sebagaimana firman Allah SWT dalam qur'an surat ali imran ayat 190 yang artinya: "sesungguhnya dalam penciptaan langit dan bumi, dan silih bergantinya malam dan siang terdapat tanda-tanda bagi orang-orang yang berakal." Yang kedua, al-qur'an memerintahkan manusia agar meneliti alam semesta. al-qur'an menyuruh manusia untuk meneliti alam semest agar mengetahui tanda-tanda kekuaaan allah dan rahasia allah yang terkandung di dalamnya. Sebagaimana firman Allah dalam qur'an surat al-yunus ayat 101 yang artinya : katakanlah: "perhatikanlah apa yang ada di langit dan di bumi. Tidaklah bermanfaat tanda kekuasaan allah dan rosul-rosul yang memberi peringatan bagi orang-orang yang tidak beriman.”

Ian G. Barbour menulis dalam karyanya: when science meets religion: enemies, strangers, or partners? Dan nature, human, nature and god. Kemudian John F. Haughts menulis science and religion:from conflict to conversation. ${ }^{11}$ Barbour membagi hubungan sains dan agama ke dalam 4 tipologi yaitu konflik, independensi, dialog, dan integrasi. ${ }^{12}$

${ }^{11}$ Nuraini, "Mengintegrasikan Agama, Filsafat, dan Sains”, Jurnal Pendidikan Islam, vol. 2, Nomor 1, Juli-Desember 2016, hal. 244

${ }^{12}$ Waston, "Hubungan Sains dan Agama: Refleksi Filosofis Atas Pemikiran Ian G. Barbour", Jurnal Studi Islam, vol. 15, Nomor 1, Juni 2014, hal. 80 
a) Tipe konflik ini memiliki pandangan bahwa sains dan agama memiliki pertentangan. Dalam hal ini pandangan tersebut mengharuskan seseorang untuk memilih salah satunya. Barbour menanggapi hal ini bahwa argumen mereka itu keliru. Setiap pandangan baik dari segi sains dan segi agama memiliki kualitas dan porsinya masingmasing. Sehingga dalam hal tersebut harus diseimbangkan.

b) Tipe independensi yang menekankan perbedaan yang ada. pemisahan antara keduanya yaitu antara sains dan agama. Karena pada dasarnya mereka itu memiliki wilayanag sendiri yang berbeda. Ketika hal ini dapat diatasi dengan adanya batasan untuk keduanya berpandangan dengan bagian masing-masing maka pertentangan tidak akan terjadi diantara keduanya. ${ }^{13}$

c) Tipe dialog yang lebih konstruktif antara sains dan agama dibandingkan dengan kedua teori sebelumnya. Hal tersebut meneliti tentang kesetaraan antara metode sains dan agama. Dalam membandingkannya dialog menekankan pada pra-anggapan, metode dan konsep. ${ }^{14}$

d) Tipe integrasi memiliki 3 versi yang berbeda. Dalam natural theology dapat diambil kesimpulan bahwa keberadaan tuhan dapat dilihat dari bentuk penciptaan alamnya. Sedangkan theology of nature, dalam pandangannya itu berada di luar sains dimana agama dan sains memiliki kontribusi pada pengembangan ilmu pengetahuan metafisika inklusif. ${ }^{15}$

Para ilmuwan menemukan kebenaran melalui penelitian secara mendalam tentang mengapa seseorang menggunakan penalaran analistis, yang punya asosiasi ke sains, serta alasan moralitas, yang erat hubungannya dengan keimanan atau agama. Sekarang ini kita dihadapkan pada perbedaan tentang penamaan antara sekolah biasa atau umum dengan sekolah yang agama atau madrasah. Dengan adanya kurikulum 2013 merupakan suatu harapan bagi sekolah madrasah atau yang dominan tentang ilmu agama untuk melakukan integrasi antara ilmu pengetahuan sains dengan agama. Dimana pendekatanya dilakukan dengan bebrapa tahap yaitu: observing, questioning, explore, associating dan communicating. ${ }^{16}$

Dalam pandangan islam, alam tidak dilihat sebagai bagian hanya memandang pada sistem ketuhanan, kemanusiaan dan dunia. Tetapi ilmu pengetahuan dan alam memiliki keterkaitan dengan agama daan tuhan. Sebagaimana disebutkan di dalam al-qur'an juga mencari ilmu pengetahuan sebagai bagian dari aspek suci yang merujuk kepada tuhan. ${ }^{17}$ Pada bagian yang lain, Ian G. Barbour merumuskan sebuah konsepsi yang mana membahas tentang integrasi agama dan ilmu pengetahuan. Singkatnya, beliau berupaya untuk

${ }^{13}$ Wedra Aprison, "Mendamaikan Sains dan Agama: Mempertimbangkan Teori Harun Nasution", Jurnal Pendidikan Islam, Vol. IV, Nomor 2, Desember 2015, hal. 246

${ }^{14}$ Waston, "Hubungan Sains dan Agama: Refleksi Filosofis Atas Pemikiran Ian G. Barbour", Jurnal Studi Islam, vol. 15, Nomor 1, Juni 2014, hal. 82

${ }^{15}$ Ibid, hal. 82

16 Masduki, "Pendidikan Islam dan Kemajuan Sains: Historisitas Pendidikan Islam yang Mencerahkan”, Jurnal Pendidikan Islam, vol. IV, Nomor 2, Desember 2015, hal. 268

${ }^{17}$ Iis Arifudin, "Integrasi Sains dan Agama Serta Implikasinya terhadap Pendidikan”, Jurnal Edukasi Islamika, vol. 1, Nomor 1, Desember 2016, hal. 165 
menyatukan keduanya di dalam bingkai suatu sistem ke filsafatan. ${ }^{18}$ Dengan sistem sains yang sekuler dan telah diaanggap sebagai sumber kebenaran yang memenuhi pikiran, bagaimana caranya kita menanamkan akidah pada generasi selanjutnya? banyak dari kita yang lebih memilih mengajarkan kepada anak yang lebih rasionalis dan kritis untuk memiliki cara pandang dari dua sisi, yaitu: percaya akan keabsahan sans dan percaya akan adanya tuhan. ${ }^{19}$ Dalam hal ini konsep ilmu pengetahuan harus sesuai dengan pembatasan yang di dalam batasan itu menjadikan tuhan sebagai pembatasnya. Agar paham sains yang sekuler tidak meracuni keimanan generasi muda.

Perealisasian akidah yang sesuai dapat diterapkan pada tempatnya. Semisal dalam proses penciptaan alam semesta, yang mana sains diartikan sebagai penciptaan ruang dan waktu serta materi dan energi, dapat kita implementasikan bahwa pembentukan alam semesta itu tidak muncul dengan sendirinya, melainkan diciptakan oleh yang maha kuasa. Allah swt menciptakan alam semesta dari awal mulanya sampai sekarang, tertera dalam alqur'an. Baik fenomena alam yang terjadi itu merupakan sebuah wujud dari hukum alam yang mana semua terjadi atas kehendak sang pencipta yaitu tuhan.

Otentitas al-qur'an adalah suatu keaslian atau kebenaran dimana semua yang terkandung di dalam al-qur'an merupakan benar adanya dari tuhan. Baik dalam redaksinya benar-benar wahyu tuhan. Kita memerlukan alat bukti yaitu dengan fakta-fakta ilmiah, bukan teori ilmiah. Hal tersebut dilakukan oleh pihak ke-3 yang tidak ada hubungannya dengan agama-agama yang ada. perlunya untuk membuktikan yaitu membenturkan ayat dengan fakta ilmiah. Pemikiran plato seorang filosof romawi yang hidup sekitar abad 4 SM (hidup 400 sebelum masehi). Pendapatnya adalah tentang bumi itu bentuknya datar. 600 tahun etelah platonada ilmuan lagi yaitu ptolomeus 200 tahun setelah masehi. Dia membenarkan teori plato namun dia menambahkan bahwa benda-benda langit mengelilingi bumi. Bumi merupakan pusat edar. 1300 tahun kemudian muncul peneliti barat bernama nicholas copernicus $(1500 \mathrm{M})$ menyipulkan bahwa bukan matahari yang berputar mengelilingi bumi, tapi justru bumi yang berputar mengelilingi matahari. Pendapat ini tidak diyakini oleh orang-orang bahkan dia dikatakan gila dan dihukum pancung. Lalu penelitian galileo galilei $(1600 \mathrm{M})$ ia sependapat dengan copernicus tentang bumi mengitari matahari. Dia mendapat perlakuan yang sama dan tidak jauh berbeda dengan copernicus. Dia dipenjara seumur hidup dan sampai mati. Semakin majunya pemikiran dan tekhnologi mereka berfikir ketika semua ilmuan dihukum maka negaranya tidak akan maju. Lalu munculah fakta yaitu teori Big Bang. Teori ini tidak terbantahkan lagi setelah penelitian yang mutakhir.

Di dalam al-qur'an disebutkan bahwa Allah yang menciptakan alam semesta beserta isinya. Hal ini terdapat pada surat al-a'raf ayat 54 yang artinya: "sesungguhnya tuhan kalian, yaitu Allah SWT, dialah yang menciptakan langit dan bumi dalam 6 hari, kemudian dia beristiwa di atas arsy."

\footnotetext{
${ }^{18}$ Ibid, hal 167

${ }^{19}$ Achmad Baiquni, Al-qur'an dan Ilmu Pengetahuan Kealaman, (Yogyakarta: Dana Bhakti Prima Yasa,
} 1997), hal. 128 


\section{Keselarasan ilmu pengetahuan (sains) dan agama Islam}

Pada surah An-Nahl ayat 11 dan 12 sangat penting sekali pemikiran kritis dan penalaran yang rasional ini bagi pengungkapan alam semesta. Dimana alam semesta dan proses-proses didalamnya merupakan ayatulloh kemudian dikaji oleh para pakar fisika dan fenomena alam yang terjadi merupakan suatu hukum alam. Menurut pandaangan orang muslim, suatu hukum alam yang merupakan hal tersebut terjadi atas dasar kuasa Allah SWT. ${ }^{20}$ Melalui pedoman di dalam al-qur'an, ilmu sains dapat berkembang untuk mengetahui sifat dan tingkah laku alam serta kondisi fenomena alam di lingkungan. ${ }^{21}$

Pembahasan tentang integrasi ilmu pengetahuan dan agama hal ini berarti kita berusaha untuk menggabungkan antara sains dan agama agar selaras, meskipun hal ini bukan berarti menyatukan dalam perspektif mencampur, karena baik ilmu pengetahuan maupun agama mempunyai substansi yang tidak harus dihilangkan, palah harusnya dipertahankan. Sejatinya ilmu dan agama lahir dari wilayah yang sama yaitu sebuah pengalaman kemanusiaan. Sampai saat ini, banyak sekali yang berfikiran bahwa ilmu sains dan agama itu berdiri sendiri dan sudah ada porsinya masing-masing. Hal tersebut memunculkan pemikiran bahwa ilmu dan agama itu tidak dapat disatukan baik dari segi formal yaitu material, metode penelitian, kriteria kebenaran, peran yang dimainkan oleh para ilmuwan. Contohnya pada ilmu fisika yang mana agama lebih berhubungan dengan kehidupan seharihari.

Harmonisasi ilmu pengetahuan dan agama islam sebenarnya sudah merupakan perwujudan dari bentuk satu kesatuan. Yang mana ketika tidak ada kesalahpahaman yang berlarut-larut maka ajaran agama islam sudah terealisasikan dengan baik. Karena agama islam sendiri memiliki ajaran-ajaran yang universal. ${ }^{22}$ Cara pandang suatu masyarakat merupakan pola pikir dari masyarakat tersebut. Ketika kita ingin menerima dan mengikuti budayabudaya yang ada, baik itu dari luar misalnya budaya barat, kita harus benar-benar mengetahui apakah budaya tersebut pantas untuk diterapkan kepada agama islam atau tidak. Jadi setiap orang harus memiliki tameng yaitu keimanan yang mana hal tersebut menggunakan ajaran agama islam yang benar dan lurus.

Ketika budaya atau ilmu yang masuk kedalam suatu lingkungan masyarakat islam, kita harus mengetahui asal muasal budaya tersebut berkembang dengan semestinya atau tidak. Ketika budaya tersebut memberikan dampak yang baik untuk kemajuan masyarakat muslim, maka tidak mengapa ketika kita harus mengambil dan mencontek budaya tersebut. Namun tak terlepas dari pandangan yang telah disyariatkan oleh agama islam. Tidak boleh menyeleweng dari aturan-aturan yang ada di dalam agama. Ketika kita melakukan proses islamisasi, maka kita juga harus menyaring dengan cermat ketika ada budaya-budaya sekuler yang melekat di dalamnya. Kita harus bijak dan teliti dalam mengadopsi suatu budaya luar.

\footnotetext{
${ }^{20}$ Achmad Baiquni, Al-qur'an dan Ilmu Pengetahuan Kealaman, (Yogyakarta: Dana Bhakti Prima Yasa, 1997), hal. 119 hal. 7

${ }^{21}$ Ibid, hal. 19

${ }^{22}$ Fahri Hidayat," Pengembangan Paradigma Integrasi Ilmu: Harmonisasi Islam dan Sains Dalam Pendidikan”, Jurnal Pendidikan Islam Vol IV, Nomor 2, Desember 2015, hal. 309
} 
Ilmu pengetahuan (sains) dan agama tidak selamanya dalam ruang lingkup yang bertentangan dan ketidaksesuaian. Banyak ilmuwan yang mencari cara agar pandangan tersebut menjadi sebuah keharmonisan diantara ilmu pengetahuan dan agama. Dalam hal ini, peran ilmu pengetahuan dan agama sangatlah penting dalam kehidupan manusia. Agama merupakan suatu tuntunan, petunjuk, tata cara, atau pedoman yang tercantum dalam kitab suci. Sedangkan sains memiliki peran pada interaksi dan komunikasi yabg terbangun dalam suatu masyarakat.

\section{Kesimpulan}

Pada dasarnya, antara ilmu pengetahuan (sains) dan agama sudah tidak perlu diintegrasikan. Karena pada dasarnya kedua hal tersebut sudah diintegrasikan dari awal mulanya atau asalnya. Di dalam al-qur'an sudah jelas disebutkan bahwa kita diajak utuk mencari atau mendapatkan ilmu. Integrasi ilmu pengetahuan (sains) dan agama islam memanglah memiliki sudut pandang yang berbeda. Namun dalam hal ini, keselarasan antara keduanya haruslah ditingkatkan. Karena keduanya memiliki peran penting dalam kehidupan manusia dan kemajuan sebuah bangsa. Agama merupakan pedoman atau tata cara atau petunjuk melalui aturan di dalam kitab suci dimana dalam ilmu pengetahuan (sains) yang berorientasi pada interaksi komunikasi yang ada di dalam masyarakat. Keduanya tentu memiliki hubungan dimana berintegrasi pada perilaku, moral, etika dan kemasyarakatan.

Keselarasan atau keharmonisasian antara ilmu pengetahuan (sains) dan agama islam seharusnya sudah dapat terealisasikan sejak munculnya agama islam. Jelas sekali dukungan atau penguat yang ada di dalam al-qur'an bahwa ajakan untuk mencari atau mendapatkan ilmu itu ada. Namun, karena perbedaan penafsiran atau cara pikir setiap individu berbeda, pastilah akan memunculkan hal-hal baru yang menyebabkan tidak bisa berjalan berdampingan atau bahkan tidak bisa dikatakan harmonis. Hal tersebut haruslah cepat diperbaiki. Karena antara ilmu pengetahuan (sains) dan agama islam itu sangat penting untuk keberlangsungan hidup seluruh masyarakat.

\section{Daftar Pustaka}

Aprison, Wedra. "Mendamaikan Sains dan Agama: Mempertimbangkan Teori Harun Nasution". Jurnal Pendidikan Islam. Vol. IV. 2015 Nomor 2.

Arifin, Zainal. "Pendidikan Islam Dalam Perspektif Filsafat Ilmu”. Jurnal Pendidikan Islam. Vol XIX. 2014. Nomor 1.

Arifudin, Iis. "Integrasi Sains dan Agama Serta Implikasinya terhadap Pendidikan”. Jurnal Edukasi Islamika. Vol. 1 2016. Nomor 1.

Baiquni, Achmad. 1997. Al-qur'an dan Ilmu Pengetahuan Kealaman. Yogyakarta: Dana Bhakti Prima Yasa.

Dahlan, Moh. "Relasi Sains Modern dan Sains Islam: Suatu Upaya Pencarian Paradigma Baru”. Jurnal Ilmu Pengetahuan Sains. Vol 12, 2009, Nomor 2.

Hidayatullah, Syarif. “Agama dan Sains: Sebuah Kajian Tentang Relasi dan Metodologi”. Jurnal Filsafat. Vol 29. 2019. Nomor 1. 
24 Integrasi Ilmu Pengetahuan ....

Hidayat, Fahri. "Pengembangan Paradigma Integrasi Ilmu: Harmonisasi Islam dan Sains Dalam Pendidikan", Jurnal Pendidikan Islam Vol IV. 2015. Nomor 2.

Masduki, "Pendidikan Islam dan Kemajuan Sains: Historisitas Pendidikan Islam yang Mencerahkan”. Jurnal Pendidikan Islam. Vol. IV. 2015. Nomor 2.

Nasr, Seyyed Hossein. 2014. Tiga Mazhab Utama Filsafat Islam (Ibnu Sina, Suhrawardi, dan Ibnu 'Arabi), Yogyakarta: IRCiSoD.

Nuraini, "Mengintegrasikan Agama, Filsafat, dan Sains", Jurnal Pendidikan Islam. Vol. 2. 2016. Nomor 1.

Soleh, Khudori. 2012. "Epistimologi Ibn Rusyd: Upaya Mempertemukan Agama \& Filsafat", Malang: UIN-MALIKI PRESS.

Waston, "Hubungan Sains dan Agama: Refleksi Filosofis Atas Pemikiran Ian G. Barbour", Jurnal Studi Islam, vol. 15, 2014, Nomor 1. 